\title{
Observation of a $\mathrm{HI}$ leaving group following ultraviolet photolysis of $\mathrm{CH}_{2} \mathrm{I}_{2}$ in water and an $a b$ initio investigation of the $\mathrm{O}-\mathrm{H}$ insertion/HI elimination reactions of the $\mathrm{CH}_{2} \mathrm{I}-\mathrm{I}$ isopolyhalomethane species with $\mathrm{H}_{2} \mathrm{O}$ and $2 \mathrm{H}_{2} \mathrm{O}$
}

\author{
Yun-Liang Li, Cunyuan Zhao, Wai Ming Kwok, Xiangguo Guan, Peng Zuo, \\ and David Lee Phillips ${ }^{\text {a) }}$ \\ Department of Chemistry, University of Hong Kong, Pokfulam Road, Hong Kong
}

(Received 31 January 2003; accepted 6 June 2003)

\begin{abstract}
We report an experimental observation of $\mathrm{H}^{+}$and $\mathrm{I}^{-}$being formed following ultraviolet photolysis of $\mathrm{CH}_{2} \mathrm{I}_{2}$ in liquid water. The concentration of $\mathrm{H}^{+}$and $\mathrm{I}^{-}$are about the same and suggest a reaction that produces a $\mathrm{HI}$ leaving group. A preliminary ab initio investigation is reported for the $\mathrm{O}-\mathrm{H}$ insertion reactions of the isodiiodomethane $\left(\mathrm{CH}_{2} \mathrm{I}-\mathrm{I}\right)$ carbenoid species with $\mathrm{H}_{2} \mathrm{O}$ and $2 \mathrm{H}_{2} \mathrm{O}$ and these are compared to the related reactions for the dichlorocarbene $\left(: \mathrm{CCl}_{2}\right)$ species. The $\mathrm{CH}_{2} \mathrm{I}-\mathrm{I}$ carbenoid reacts with water via an $\mathrm{O}-\mathrm{H}$ insertion/HI elimination reaction mechanism. These reactions produce a $\mathrm{HI}$ leaving group whereas the dichlorocarbene $\mathrm{O}-\mathrm{H}$ insertion reaction has no need for a leaving group. The differing structures and properties of the $\mathrm{CH}_{2} \mathrm{I}-\mathrm{I}$ and the $: \mathrm{CCl}_{2}$ species can account for the differences in their $\mathrm{O}-\mathrm{H}$ insertion reactions. The $\mathrm{CH}_{2} \mathrm{I}-\mathrm{I}$ species $\mathrm{O}-\mathrm{H}$ insertion/HI elimination reactions can be catalyzed by a second water molecule when two water molecules are available and this occurs in a way similar to that previously observed for the reaction of : $\mathrm{CCl}_{2}$ with two water molecules. These results suggest that isopolyhalomethane molecules (like $\mathrm{CH}_{2} \mathrm{I}-\mathrm{I}$ and others) are noticeably reactive towards $\mathrm{O}-\mathrm{H}$ bonds like those found in water and can likely account for the strong acid formation observed experimentally after ultraviolet photolysis of polyhalomethanes in water. Possible implications for the photochemistry of polyhalomethanes in the atmosphere and oceans are briefly discussed. (C) 2003 American Institute of Physics.
\end{abstract}

[DOI: $10.1063 / 1.1595636]$

\section{INTRODUCTION}

Polyhalomethanes and their associated photochemistry and chemistry have long been studied due to their interest in several different areas of chemistry. Polyhalomethanes like $\mathrm{CH}_{2} \mathrm{I}_{2}, \mathrm{CH}_{2} \mathrm{ClI}, \mathrm{CH}_{2} \mathrm{BrI}, \mathrm{CHBr}_{3}, \mathrm{CCl}_{4}, \mathrm{CFCl}_{3}$, and others have been observed in the atmosphere and are believed to be important sources of reactive halogens in the atmosphere. ${ }^{1-8}$ Several polyhalomethanes have found utility as reagents for the cyclopropanation of olefins as well as diiodomethylation of carbonyl molecules. ${ }^{9-16}$ For instance, cyclopropanated products can be made from olefins in reasonable yields with high stereospecificity by ultraviolet photolysis of $\mathrm{CH}_{2} \mathrm{I}_{2}$ in the presence of olefins in room temperature solutions. ${ }^{10,11,13}$ Polyhalomethanes have also been used as prototypes for studying fundamental aspects of photodissociation processes. $^{17-33}$

Ultraviolet photolysis of polyhalomethanes generally leads to direct carbon-halogen bond cleavage reactions in the gas phase $\mathrm{e}^{17-33}$ and molecular beam anisotropy measurements demonstrated these reactions usually take place in times much less than a rotational period of the parent molecule. ${ }^{17,19,22-26,29,31}$ The polyatomic photofragments from these photodissociation reactions generally receive substan-

\footnotetext{
a) Author to whom correspondence should be addressed. Electronic mail: phillips@hkucc.hku.hk
}

tial degrees of internal excitation of their vibrational and/or rotational degrees of freedom as shown by time-of-flight photofragment spectroscopy experiments. ${ }^{19,22-26}$ Ultraviolet resonance Raman investigations for a number of polyhalomethanes in both gas and solution phase environments showed that the photodissociation reactions usually had a significant multidimensional character and Franck-Condon region dynamics qualitatively consistent with a semirigid radical description of the dissociation process. ${ }^{34-43}$

Photoexcitation of polyhalomethanes in the ultraviolet in condensed phase media gives rise to photoproducts with characteristic transient absorption bands in the ultraviolet and visible regions that were tentatively assigned to a number of different species. ${ }^{44-50}$ Recent femtosecond transient absorption experiments indicate these photoproducts are formed by geminate recombination of the photofragments within the solvent cage. ${ }^{51-55}$ The intense transient absorption bands observed after ultraviolet photolysis of $\mathrm{CH}_{2} \mathrm{I}_{2}$ in the condensed phase environments were assigned to be mainly due to an isodiiodomethane $\left(\mathrm{CH}_{2} \mathrm{I}-\mathrm{I}\right)$ product based on IR vibrational frequencies observed in low temperature matrix isolation experiments by Maier and co-workers. ${ }^{46,47}$ Femtosecond time-resolved absorption experiments showed similar intense transient absorption bands are also formed very quickly in room temperature solutions and Akesson and co-workers ${ }^{53}$ also assigned these bands to be due to the $\mathrm{CH}_{2} \mathrm{I}-\mathrm{I}$ species and this was confirmed by nanosecond and 
picosecond time-resolved resonance Raman experiments. ${ }^{56,57}$ Further time-resolved absorption ${ }^{53-55}$ and resonance Raman experiments ${ }^{56-63}$ showed that isopolyhalomethane photoproducts were mainly responsible for the ultraviolet transient absorption bands observed on the picosecond and nanosecond time scales in liquids.

The chemical reactivity of isopolyhalomethanes towards olefins has been investigated both experimentally and theoretically ${ }^{64-69}$ Density functional theory (DFT) calculations found the $\mathrm{CH}_{2} \mathrm{I}-\mathrm{I}$ species can react easily with ethylene to make a cyclopropane product and $\mathrm{I}_{2}$ leaving group via a one-step reaction mechanism with a small $2.9 \mathrm{kcal} / \mathrm{mol}$ barrier to reaction. ${ }^{64}$ However, the $\mathrm{CH}_{2} \mathrm{I}$ radical and $\mathrm{CH}_{2} \mathrm{I}^{+}$cation species reacted with ethylene via a two step reaction mechanism that forms relatively stable iodopropyl radical or iodopropyl cation intermediates that have much higher barriers to reaction to form cyclopropane product. ${ }^{64}$ Timeresolved resonance Raman $\left(\mathrm{TR}^{3}\right)$ experiments demonstrated that $\mathrm{CH}_{2} \mathrm{I}-\mathrm{I}$ reacts with cyclohexene on the 5-10 ns time scale to produce an $\mathrm{I}_{2}$ leaving group that forms an $\mathrm{I}_{2}$ : cyclcohexene complex. ${ }^{66}$ These $\mathrm{TR}^{3}$ experiments were done under conditions similar to those employed by the original photochemical studies of Blomstrom, Herbig, and Simmons that found significant conversion of $\mathrm{CH}_{2} \mathrm{I}_{2}$ into norcarane product (e.g., the cyclopropanated product of cyclohexene). ${ }^{10}$ The experimental and theoretical results indicate $\mathrm{CH}_{2} \mathrm{I}-\mathrm{I}$ is the carbenoid species mainly responsible for the cyclopropanation of olefins when employing the ultraviolet photolysis of $\mathrm{CH}_{2} \mathrm{I}_{2}$ method and a reaction mechanism was proposed. ${ }^{64,66}$ Additional work found several other isopolyhalomethanes are able to act as carbenoids to varying degrees of reactivity towards olefins. ${ }^{56,67,68}$ The reactivity of $\mathrm{CH}_{2} \mathrm{I}-\mathrm{I}$ was found to be similar to that of singlet methylene towards carbon double bonds to form cyclopropanated products with high stereospecificity and little $\mathrm{C}-\mathrm{H}$ insertion products. $^{70,71}$

Carbenes and carbenoids are also able to undergo $\mathrm{O}-\mathrm{H}$ insertion reactions with alcohols and water. ${ }^{72-79}$ For example, singlet methylene can react with water to form $\mathrm{CH}_{3} \mathrm{OH}^{72-77}$ Dichlorocarbene $\left(: \mathrm{CCl}_{2}\right)$ can also react with water to form $\mathrm{O}-\mathrm{H}$ insertion reaction products. ${ }^{78,79}$ We have recently used picosecond time-resolved resonance Raman spectroscopy to observe the formation and decay of $\mathrm{CH}_{2} \mathrm{I}-\mathrm{I}$ in largely aqueous solvents. ${ }^{80}$ This study demonstrated that $\mathrm{CH}_{2} \mathrm{I}-\mathrm{I}$ can be formed to an appreciable extent via geminate recombination of the $\mathrm{CH}_{2} \mathrm{I}$ radical and I fragments in aqueous environments following ultraviolet photolysis of $\mathrm{CH}_{2} \mathrm{I}_{2} \cdot{ }^{80}$

In this paper, we report the experimental observation of the production of $\mathrm{H}^{+}$and $\mathrm{I}^{-}$after ultraviolet photolysis of $\mathrm{CH}_{2} \mathrm{I}_{2}$ in water and explore the chemical reactivity of isopolyhalomethanes towards water using ab initio calculations and the $\mathrm{CH}_{2} \mathrm{I}-\mathrm{I}$ isopolyhalomethane species as an example. We find that the $\mathrm{CH}_{2} \mathrm{I}-\mathrm{I}$ isopolyhalomethane is able to react with water via $\mathrm{O}-\mathrm{H}$ insertion/HI elimination reactions. When two water molecules are present, the $\mathrm{CH}_{2} \mathrm{I}-\mathrm{I}$ species $\mathrm{O}-\mathrm{H}$ insertion/HI elimination reactions can be catalyzed by the second water molecule in a manner similar to that previously found for the reaction of dichlorocarbene $\left(\mathrm{CCl}_{2}\right)$ with two water molecules. ${ }^{79}$ Our results suggest that isopolyhalomethane molecules are reasonably reactive towards $\mathrm{O}-\mathrm{H}$ bonds such as those found in water and can release a strong acid leaving group. This can probably explain the experimental observation of $\mathrm{H}^{+}$and $\mathrm{I}^{-}$formation after ultraviolet photolysis of $\mathrm{CH}_{2} \mathrm{I}_{2}$ in water solution. We briefly discuss possible implications for the photochemistry of polyhalomethanes in the atmosphere and oceans.

\section{EXPERIMENT AND CALCULATIONS}

Sample solutions were prepared using commercially available $\mathrm{CH}_{2} \mathrm{I}_{2}(99 \%)$ and deionized water. The sample solution of about $1.5 \times 10^{-4} \mathrm{M} \mathrm{CH}_{2} \mathrm{I}_{2}$ in water was housed in a $3 \mathrm{~cm}$ quartz tube and excited by an about $1 \mathrm{~mJ} 266 \mathrm{~nm}$ unfocused laser beam from the fourth harmonic of a Nd:YAG laser in the photolysis experiments. The absorption spectra for the photolyzed samples were obtained using a 1 $\mathrm{cm}$ ultraviolet (UV) grade cell and a Perkin Elmer Lambda 19 UV/VIS spectrometer. The $\mathrm{pH}$ of the photolyzed samples was monitored using an Orion $210 \mathrm{~A} \mathrm{pH}$ meter equipped with a $910600 \mathrm{Ag}-\mathrm{Ag}-\mathrm{Cl}$ combination $\mathrm{pH}$ electrode that was calibrated with 6.85 and $4.00 \mathrm{pH}$ buffer solutions.

All of the $a b$ initio and density-functional theory (DFT) calculations reported here made use of the GAUSSIAN 98 series of programs. ${ }^{81}$ B3LYP computations ${ }^{82-86}$ with a $6-311 \mathrm{G}^{* *}$ basis set were done for two previously studied dichlorocarbene + water reactions in order to test the density functional theory calculations for carbene $\mathrm{O}-\mathrm{H}$ insertion reactions. MP2/6-311G** calculations were also done for the : $\mathrm{CCl}_{2}+\mathrm{H}_{2} \mathrm{O}$ reaction and compared to the DFT results and previously reported $a b$ initio results. ${ }^{78,79}$ The MP2 method was employed to examine the $\mathrm{CH}_{2} \mathrm{I}-\mathrm{I}+\mathrm{H}_{2} \mathrm{O}$ and $\mathrm{CH}_{2} \mathrm{I}-\mathrm{I}$ $+2 \mathrm{H}_{2} \mathrm{O}$ reaction mechanism and compared to the : $\mathrm{CCl}_{2}$ $+\mathrm{H}_{2} \mathrm{O}$ and $: \mathrm{CCl}_{2}+2 \mathrm{H}_{2} \mathrm{O}$ reactions. These MP2 geometry optimization and frequency calculations were done with the 6-31G* basis set for all $\mathrm{C}, \mathrm{H}, \mathrm{O}$ atoms and $6-311 \mathrm{G}^{* *}$ basis set for iodide atoms in order to make the calculations tractable for our computational resources.

Analytical frequency calculations were performed to confirm the optimized structures were either a minimum or first-order saddle point. These calculations were also used to obtain the zero-point energy correction that was used without scaling. Intrinsic reaction coordinate (IRC) calculations ${ }^{87,88}$ were used to confirm the transition states connected the relevant reactants and products. The Cartesian coordinates, total energies and vibrational zero-point energies for selected stationary structures given in Figs. 2-5 are provided in the supporting information (see Ref. 89).

\section{RESULTS AND DISCUSSION}

\section{A. Experimental observation of $\mathrm{H}^{+}$and $\mathrm{I}^{-}$ production following ultraviolet photolysis of $\mathrm{CH}_{2} \mathrm{I}_{2}$ in liquid water}

Figure 1 (top) displays the absorption spectra obtained during the photolysis experiments using an unfocused 266 $\mathrm{nm}$ laser beam to excite about $1.5 \times 10^{-4} \mathrm{M} \mathrm{CH}_{2} \mathrm{I}_{2}$ in pure water. The parent $\mathrm{CH}_{2} \mathrm{I}_{2}$ absorption bands in the 280-320 $\mathrm{nm}$ region decrease in intensity and a new band at $\sim 220 \mathrm{~nm}$ 

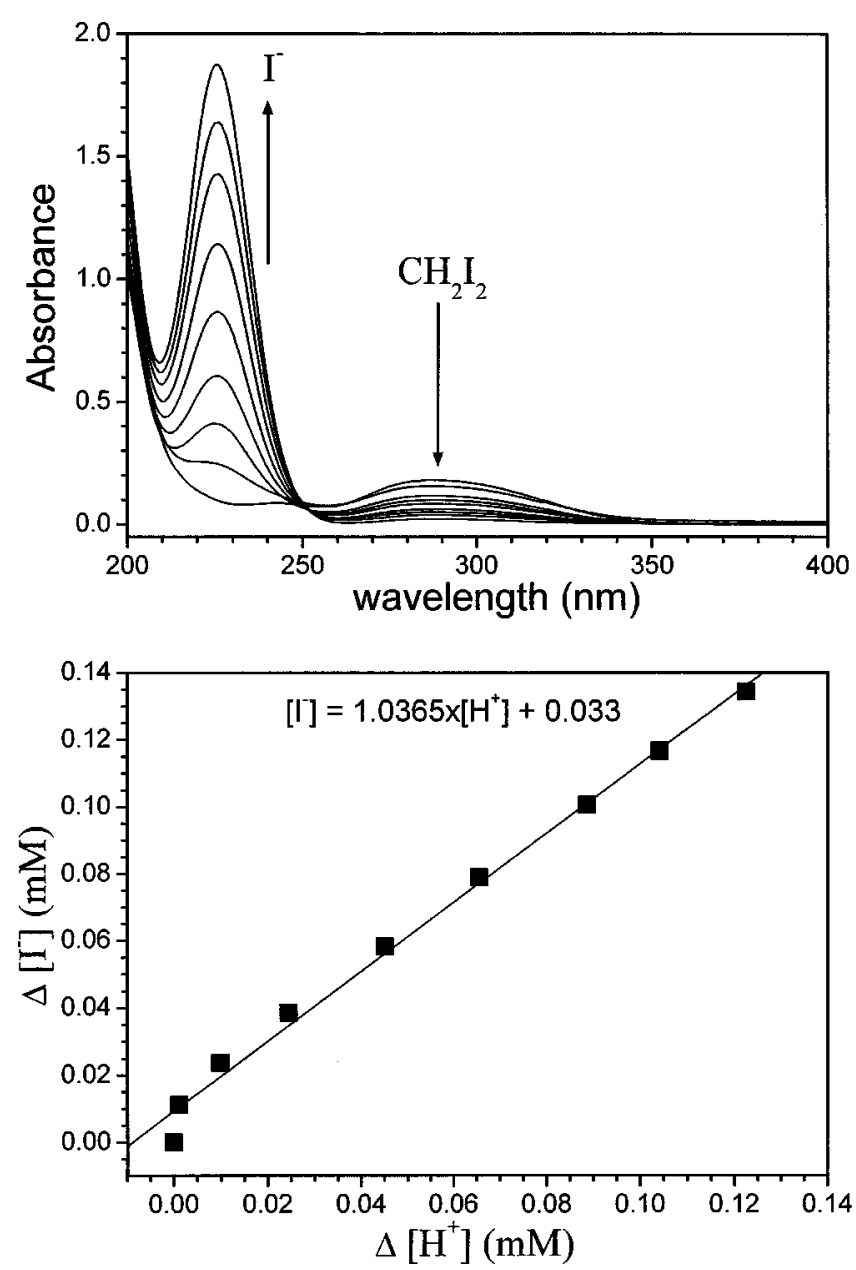

FIG. 1. (Top) Absorption spectra acquired after $266 \mathrm{~nm}$ photolysis of 1.5 $\times 10^{-4} \mathrm{M} \mathrm{CH}_{2} \mathrm{I}_{2}$ in pure water. The parent $\mathrm{CH}_{2} \mathrm{I}_{2}$ absorption bands in the $280-320 \mathrm{~nm}$ region decrease in intensity with increasing photolysis and a new absorption band at $220 \mathrm{~nm}$ due to $\mathrm{I}^{-}$appears with a clear isobestic point with the parent $\mathrm{CH}_{2} \mathrm{I}_{2}$ bands. (Bottom) Plot of $\left[\mathrm{I}^{-}\right]$vs $\left[\mathrm{H}^{+}\right]$deduced from the spectra for $\mathrm{I}^{-}$in the above spectra and $\mathrm{pH}$ measurements taken during the same experiments. The line is a linear best fit to the data and has a slope of about 1 .

appears and increases in intensity with increasing photolysis times. The $\sim 220 \mathrm{~nm}$ absorption band is essentially identical to that for $\mathrm{I}^{-}$found from a solution of KI dissolved in water (not shown). Thus, the band at $220 \mathrm{~nm}$ in Fig. 1 is assigned to be due to the $\mathrm{I}^{-}$species. There is an obvious isobestic point between the $\mathrm{CH}_{2} \mathrm{I}_{2}$ absorption and the new $\mathrm{I}^{-}$absorption bands and this indicates that ultraviolet photolysis of $\mathrm{CH}_{2} \mathrm{I}_{2}$ in water leads to fast formation of an $\mathrm{I}^{-}$product. The concentration of the $\mathrm{I}^{-}$species was found from comparison of the spectra in Fig. 1 to the measured molar extinction coefficient for $\mathrm{I}^{-}$using a standard KI aqueous solution. The $p \mathrm{H}$ was monitored during the photolysis experiments and the concentration of $\mathrm{H}^{+}$was deduced from the $\mathrm{pH}$ meter measurements. The concentration of $\mathrm{I}^{-}$and $\mathrm{H}^{+}$produced during the photolysis experiment were plotted relative to each other at the bottom of Fig. 1. Inspection of the plot in Fig. 1 shows a linear correlation between the $\mathrm{I}^{-}$and $\mathrm{H}^{+}$produced from the photolysis experiment. A linear best-fit curve (shown as a solid line in the plot of $\left[\mathrm{I}^{-}\right]$versus $\left[\mathrm{H}^{+}\right]$in Fig. 1) found a slope of about 1 . This indicates that $\mathrm{H}^{+}$and $\mathrm{I}^{-}$are formed together following ultraviolet photolysis of $\mathrm{CH}_{2} \mathrm{I}_{2}$ in water solution and are likely made from the very fast and spontaneous dissolution of a HI leaving group from the photolysis reaction.

We recently observed in picosecond time-resolved resonance Raman experiments $\left(\mathrm{ps}-\mathrm{TR}^{3}\right)^{80}$ that significant amounts of $\mathrm{CH}_{2} \mathrm{I}-\mathrm{I}$ (isodiiodomethane) can be produced after ultraviolet photolysis of $\mathrm{CH}_{2} \mathrm{I}_{2}$ in largely aqueous solutions within a few ps via geminate recombination of the initially produced $\mathrm{CH}_{2} \mathrm{I}$ radical and I atom photofragments. The $\mathrm{CH}_{2} \mathrm{I}-\mathrm{I}$ species lifetime in the ps- $\mathrm{TR}^{3}$ experiments was found to decrease with increasing $\mathrm{O}-\mathrm{H}$ bond concentration in the mixed aqueous solvents and it was suggested this could be due to some reaction of $\mathrm{CH}_{2} \mathrm{I}-\mathrm{I}$ with $\mathrm{O}-\mathrm{H}$ bonds in water and methanol. In the next two sections we explore the chemical reactivity of the known $\mathrm{O}-\mathrm{H}$ insertion reaction of the dichlorocarbene species with water and compare it to the probable $\mathrm{O}-\mathrm{H}$ insertion reaction of the $\mathrm{CH}_{2} \mathrm{I}-\mathrm{I}$ species with water.

\section{B. Reactions of dichlorocarbene $\left(: \mathrm{CCl}_{2}\right)$ with $\mathrm{H}_{2} \mathrm{O}$ and $2 \mathrm{H}_{2} \mathrm{O}$}

Becke three parameter Lee-Yang-Parr (B3LYP)/6$311 \mathrm{G}^{* *}$ density-functional theory (DFT) calculations and MP2/6-311G** ab initio calculations were done to study the reactions of : $\mathrm{CCl}_{2}+\mathrm{H}_{2} \mathrm{O}$ and $: \mathrm{CCl}_{2}+2 \mathrm{H}_{2} \mathrm{O}$ to produce a $\mathrm{CHCl}_{2} \mathrm{OH}$ product in order to compare the two methods for these types of $\mathrm{O}-\mathrm{H}$ insertion reactions and to serve as a prototype for comparison to the results in the next section for the $\mathrm{CH}_{2} \mathrm{I}-\mathrm{I}$ reactions with water that are the main focus of this paper. Figures 2 and 3 present schematic diagrams of the optimized geometry of the reactants, intermediates, transition states and products found for these reactions respectively along with the relative energies (in $\mathrm{kcal} / \mathrm{mol}$ ) for the stationary points along the reaction pathway. Both kinds of calculations gave similar optimized geometry structures for the stationary points for the $: \mathrm{CCl}_{2}+\mathrm{H}_{2} \mathrm{O}$ reaction. The barriers to reaction were found to be $14.7 \mathrm{kcal} / \mathrm{mol}$ from B3LYP/6-311G** and $14.2 \mathrm{kcal} / \mathrm{mol}$ from second-order Moller-Plesset (MP2)/6-311G**, and are in good agreement with the $13.43 \mathrm{kcal} / \mathrm{mol}$ value from $a b$ initio calculations previously reported by Pliego and De Almeida for the $: \mathrm{CCl}_{2}+\mathrm{H}_{2} \mathrm{O}$ reaction. ${ }^{78} \mathrm{~A}$ minor difference between our results and those previously reported is that our calculations predict the initial formation of a weak complex species (IM1) compared to the separated reactants. The complex formation is weak and does not significantly change the barrier to reaction or the reaction pathway for the $\mathrm{OH}$ insertion reaction. We also obtained a product complex IM2 that easily rotates via TS2 to give the final product $\left(\mathrm{CHCl}_{2} \mathrm{OH}\right)$. Again this is a flat part of the potential in the exit channel and does not significantly affect the overall reaction. Inspection of the B3LYP/6-311G** results shown in Fig. 3 reveals that the $: \mathrm{CCl}_{2}$ species forms a cyclic trimer intermediate IM3 that can then further react via a small barrier through TS3 to produce a $\mathrm{CHCl}_{2} \mathrm{OH}$ product and $\mathrm{H}_{2} \mathrm{O}$ leaving group in the overall reaction. Similar to the $\mathrm{CCl}_{2}+\mathrm{H}_{2} \mathrm{O}$ reaction, there is again the initial formation of a weak product complex 


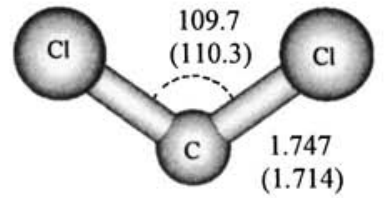

$\mathrm{CCl}_{2}$

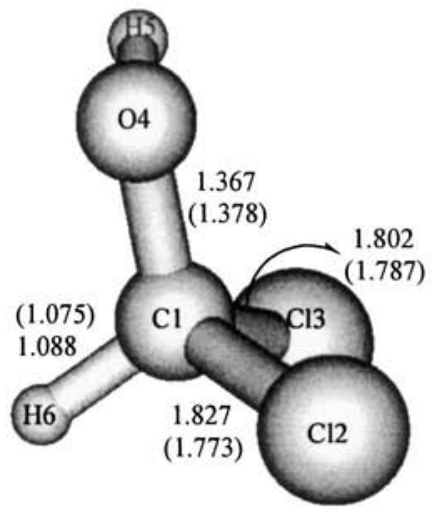

TS2

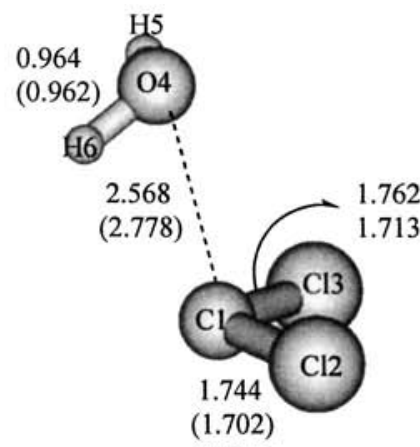

IM1

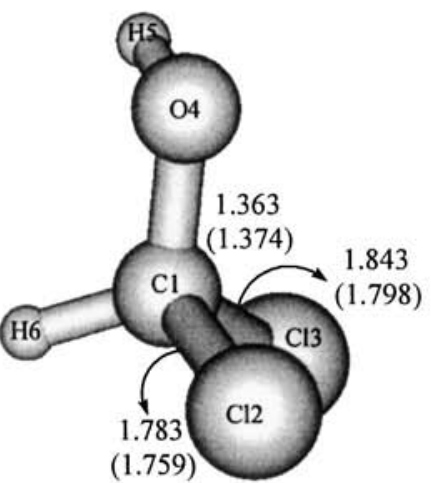

IM2

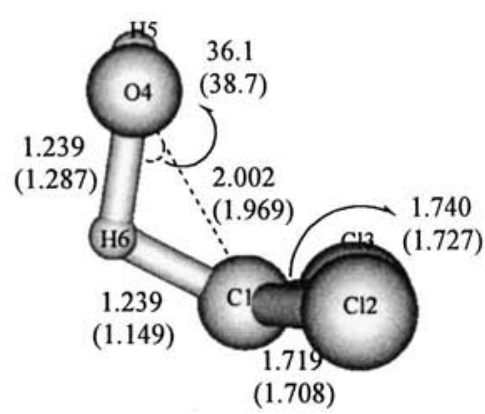

TS1

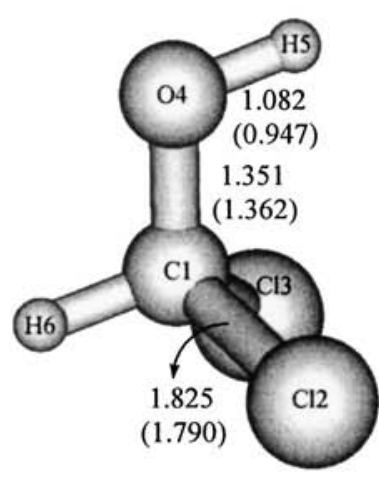

$\mathrm{CHCl}_{2} \mathrm{OH}$

(a)

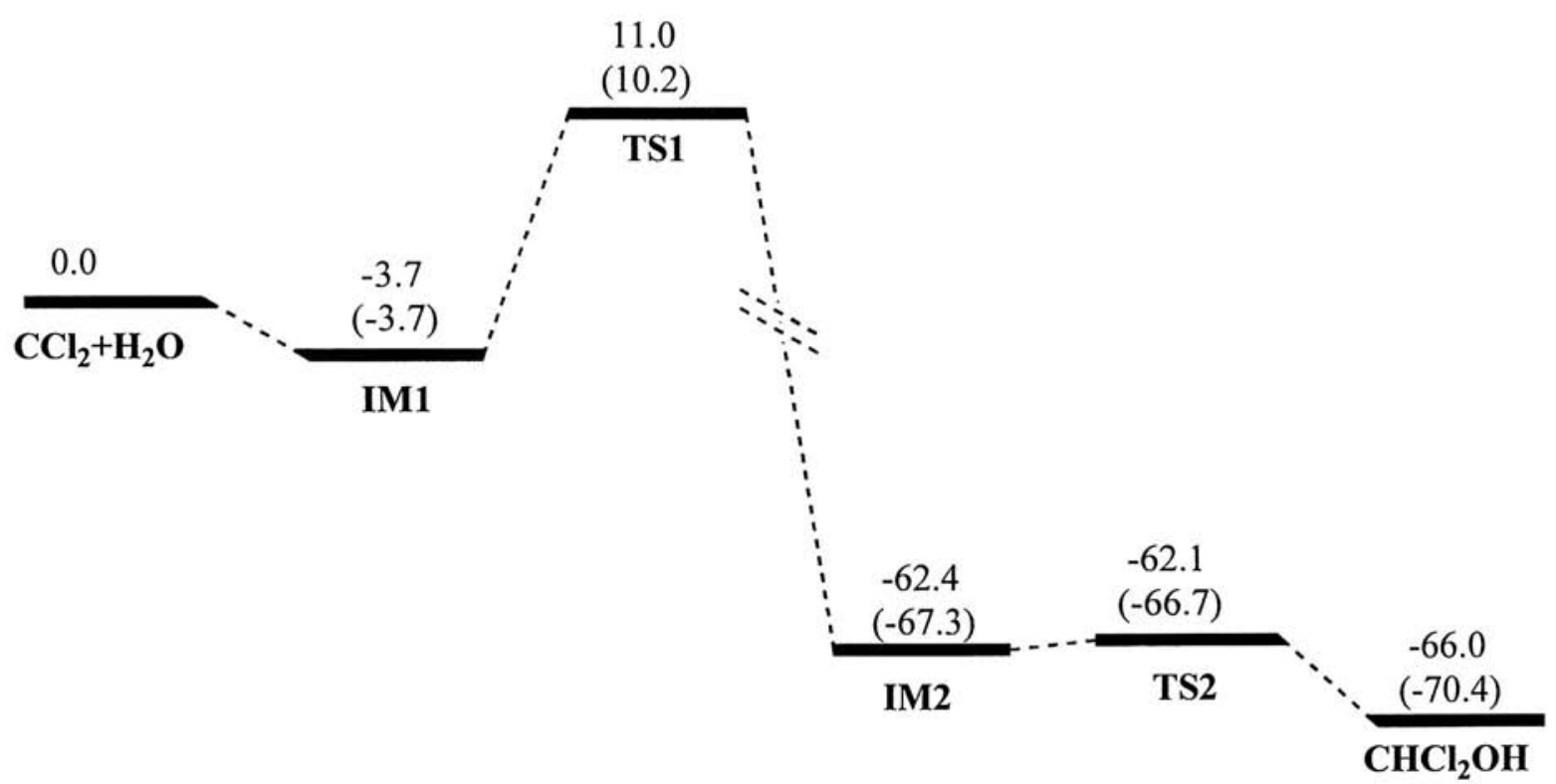

(b)

FIG. 2. (a) Schematic diagram of the B3LYP/6-311G**optimized geometry for selected reactants, intermediates, transition states and products for the reaction of : $\mathrm{CCl}_{2}+\mathrm{H}_{2} \mathrm{O}$ to produce $\mathrm{CHCl}_{2} \mathrm{OH}$. Selected geometry parameters with bond lengths in $\AA$ and bond angles in degrees are shown. (b) Relative energy profiles (in kcal/mol) are shown for the : $\mathrm{CCl}_{2}+\mathrm{H}_{2} \mathrm{O} \rightarrow \mathrm{CHCl}_{2} \mathrm{OH}$ reaction from B3LYP/6-311G** calculations. Values in parentheses in parts (a) and (b) are from MP2/6-311G** calculations. 


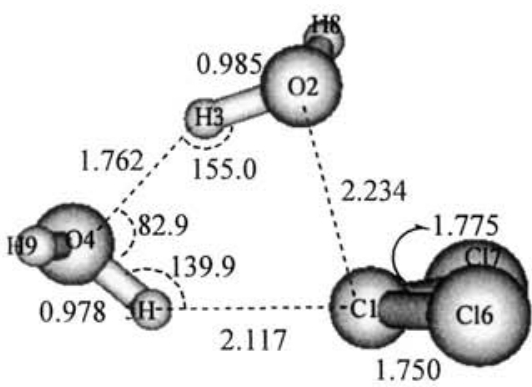

IM3

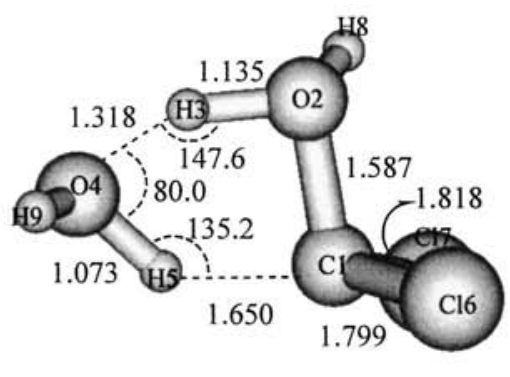

TS3

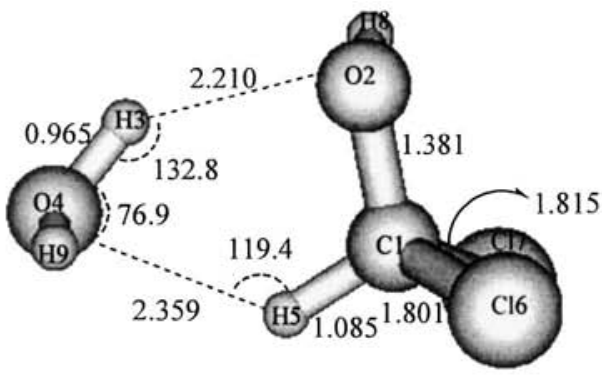

TS4

(a)

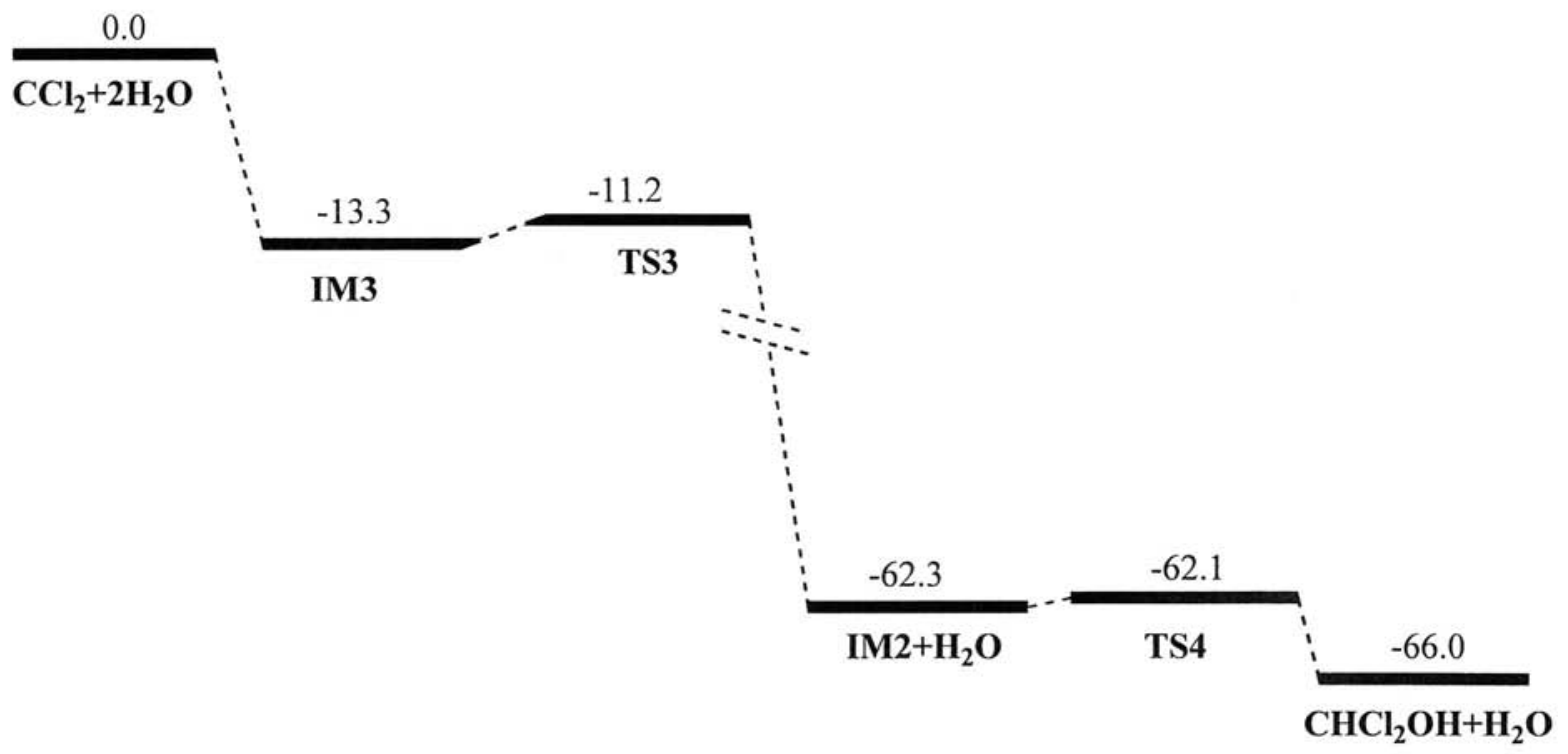

(b)

FIG. 3. (a) Schematic diagram of the B3LYP/6-311G** optimized geometry for selected reactants, intermediates, transition states, and products for the reaction of : $\mathrm{CCl}_{2}+2 \mathrm{H}_{2} \mathrm{O}$ to produce $\mathrm{CHCl}_{2} \mathrm{OH}+\mathrm{H}_{2} \mathrm{O}$. Selected geometry parameters with bond lengths in $\AA$ and bond angles in degrees are shown. (b) Relative energy profiles (in kcal/mol) are shown for the : $\mathrm{CCl}_{2}+2 \mathrm{H}_{2} \mathrm{O} \rightarrow \mathrm{CHCl}_{2} \mathrm{OH}+\mathrm{H}_{2} \mathrm{O}$ reaction from B3LYP/6-311G** level of theory.

$\left(\mathrm{IM} 2+\mathrm{H}_{2} \mathrm{O}\right)$ that undergoes rotation (via TS4) to give the final products $\mathrm{CHCl}_{2} \mathrm{OH}+\mathrm{H}_{2} \mathrm{O}$. The second $\mathrm{H}_{2} \mathrm{O}$ molecule acts as a catalyst in this reaction. The results in Fig. 3 are similar to and in good overall agreement with MP2 and MP4 $a b$ initio calculations previously reported for this reaction by Pliego and De Almeida. ${ }^{79}$ The B3LYP/6-311G** optimized geometry in Fig. 3 predicts a somewhat stronger interaction between the three molecules in the initially formed intermediate IM3 than that previously found from the MP2/DZP $a b$ initio calculations. ${ }^{79}$ For example, the $\mathrm{C}-\mathrm{O}, \mathrm{O}-\mathrm{H}$, and $\mathrm{C}-\mathrm{H}$ intermolecular distances are 2.234, 1.762, and $2.117 \AA$, respectively, for the B3LYP/6-311G** structure in Fig. 3 and $2.798,1.902$, and $2.068 \AA$, respectively, for the MP2/DZP structure. ${ }^{79}$ The B3LYP/6-311G** and MP2/DZP computed structures are more similar to one another for the transition state TS3 for the reaction. For example, the $\mathrm{C}-\mathrm{O}, \mathrm{O}-\mathrm{H}$, and $\mathrm{C}-\mathrm{H}$ intermolecular distances are $1.587,1.318$, and $1.650 \AA$, respectively, for the $\mathrm{B} 3 \mathrm{LYP} / 6-311 \mathrm{G}^{* *}$ structure in Fig. 3 and $1.605,1.356$, and $1.648 \AA$, respectively, for the MP2/ DZP structure. ${ }^{79}$ The relative energies between the stationary points for the $: \mathrm{CCl}_{2}+2 \mathrm{H}_{2} \mathrm{O}$ reaction for the $\mathrm{B} 3 \mathrm{LYP} / 6-311 \mathrm{G}^{* *}$ are also in reasonable agreement with those previously found from the MP2 and MP4

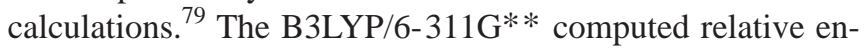
ergy of $-13.3 \mathrm{kcal} / \mathrm{mol}$ for IM3 relative to the separated reactants agrees well with the MP2/DZP, MP4(SDQ)/ccpVDZ, and MP4/cc-pVTZ values of -14.96 , -14.32 , and $-13.54 \mathrm{kcal} / \mathrm{mol}$, respectively, reported previously. ${ }^{79}$ The barrier to reaction from the IM3 intermediate to the TS3 transition state was found to be $2.1 \mathrm{kcal} / \mathrm{mol}$ for the 

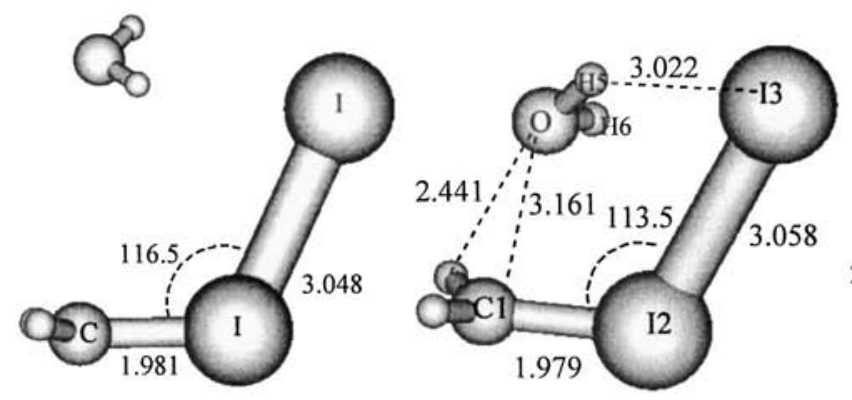

$\mathrm{CH}_{2} \mathrm{I}-\mathrm{I}+\mathrm{H}_{2} \mathrm{O}$

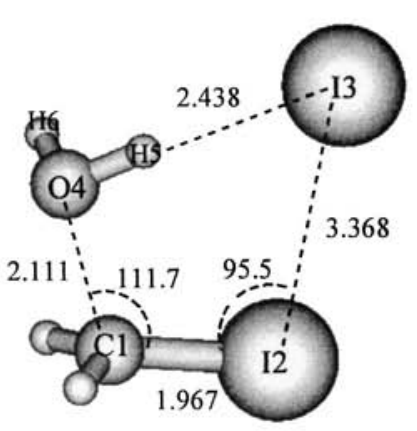

TS5

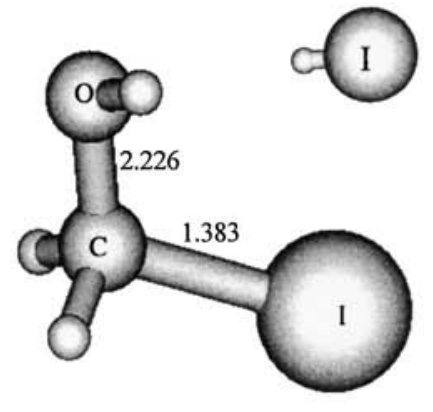

$\mathrm{CH}_{2} \mathrm{IOH}+\mathrm{HI}$

(a)

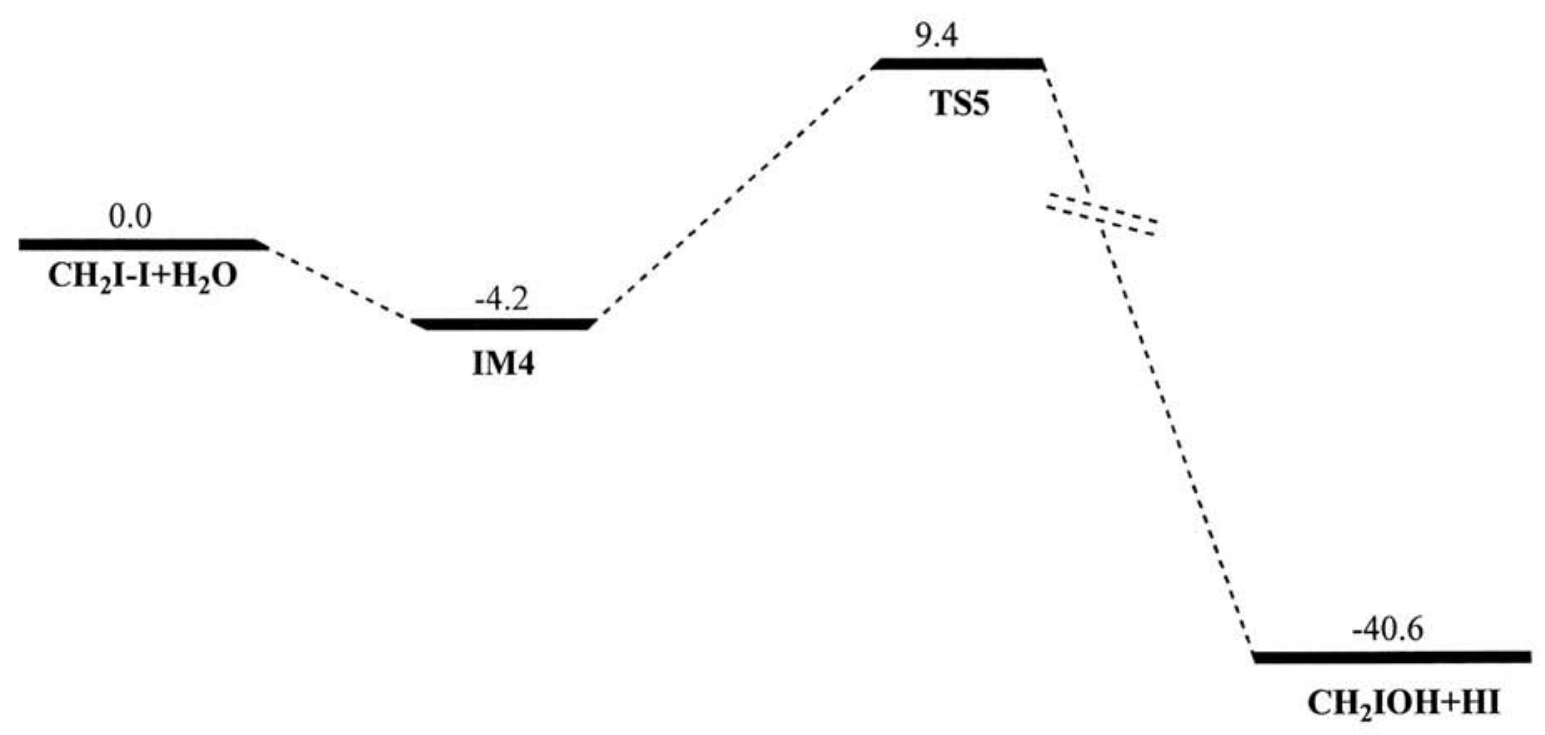

(b)

FIG. 4. (a) Schematic diagram of the MP2 computed optimized geometry for selected reactants, intermediates, transition states and products for the reaction of $\mathrm{CH}_{2} \mathrm{I}-\mathrm{I}+\mathrm{H}_{2} \mathrm{O}$. Selected geometry parameters are given with bond lengths in $\AA$ and bond angles in degrees. (b) Relative energy profiles (in kcal/mol) are displayed for the $\mathrm{CH}_{2} \mathrm{I}-\mathrm{I}+\mathrm{H}_{2} \mathrm{O}$ reactions from MP2 calculations.

B3LYP/6-311G** calculations and this is reasonably close to the values found from previous ab initio calculations (3.34 $\mathrm{kcal} / \mathrm{mol}$ for MP2/DZP, $3.54 \mathrm{kcal} / \mathrm{mol}$ for MP4/cc-pVDZ, $0.95 \mathrm{kcal} / \mathrm{mol}$ for MP2/cc-pVTZ and 5.47 for MP4/cc-pVTZ calculations). ${ }^{79}$ The results in Figs. 2 and 3 are mainly given here for comparison to the results for the $\mathrm{CH}_{2} \mathrm{I}-\mathrm{I}+\mathrm{H}_{2} \mathrm{O}$ and $\mathrm{CH}_{2} \mathrm{I}-\mathrm{I}+2 \mathrm{H}_{2} \mathrm{O}$ reactions discussed in the next section.

\section{Reactions of $\mathrm{CH}_{2} \mathrm{I}-\mathrm{I}$ with $\mathrm{H}_{2} \mathrm{O}$ and $2 \mathrm{H}_{2} \mathrm{O}$ and comparison to reactions of dichlorocarbene ( : $\mathrm{CCl}_{2}$ ) with $\mathrm{H}_{2} \mathrm{O}$ and $2 \mathrm{H}_{2} \mathrm{O}$}

The MP2 calculations gave somewhat better agreement with previous theoretical work on the dichlorocarbene $\mathrm{O}-\mathrm{H}$ insertion reactions with water ${ }^{78,79}$ than the DFT computations. This and the likely hood that MP2 calculations are probably more reliable for relatively flat potential energy surfaces led us to choose the MP2 method to investigate the probable $\mathrm{O}-\mathrm{H}$ insertion reactions of the $\mathrm{CH}_{2} \mathrm{I}-\mathrm{I}$ carbenoid with water. Figure 4 presents the optimized geometry of the stationary structures and the relative energies for the reaction of the $\mathrm{CH}_{2} \mathrm{I}-\mathrm{I}$ species with $\mathrm{H}_{2} \mathrm{O}$. Comparison of the results in Fig. 4 with those in Fig. 2 shows that there are some noticeable differences between the $\mathrm{O}-\mathrm{H}$ insertion reactions of $\mathrm{CH}_{2} \mathrm{I}-\mathrm{I}$ and $: \mathrm{CCl}_{2}$ with $\mathrm{H}_{2} \mathrm{O}$. These differences can be ascribed to the differences in the structure and properties of the $\mathrm{CH}_{2} \mathrm{I}-\mathrm{I}$ and $: \mathrm{CCl}_{2}$ species. Both $\mathrm{Cl}$ atoms are bonded to 
the $\mathrm{C}$ atom in : $\mathrm{CCl}_{2}$ and its reaction does not have a leaving group and this results in a direct $\mathrm{O}-\mathrm{H}$ insertion reaction to produce a $\mathrm{CHCl}_{2} \mathrm{OH}$ product. In contrast, the $\mathrm{CH}_{2} \mathrm{I}-\mathrm{I}$ carbenoid has only one I atom attached to the $\mathrm{C}$ atom and the second $\mathrm{I}$ atom is attached to the first $\mathrm{I}$ atom to form a weak I-I bond. This results in the $\mathrm{CH}_{2} \mathrm{I}-\mathrm{I}$ species being able to interact differently with the $\mathrm{H}_{2} \mathrm{O}$ molecule so as to first form a reaction complex with hydrogen bondinglike interactions with the terminal I atom and a ring structure as shown in IM4. This helps facilitate the $\mathrm{O}-\mathrm{H}$ insertion reaction of $\mathrm{CH}_{2} \mathrm{I}-\mathrm{I}$ with $\mathrm{H}_{2} \mathrm{O}$ to produce a $\mathrm{HI}$ leaving group and $\mathrm{CH}_{2} \mathrm{IOH}$ product. The weak I-I bond in the $\mathrm{CH}_{2} \mathrm{I}-\mathrm{I}$ species is the easiest one to break and form a leaving group for the $\mathrm{O}-\mathrm{H}$ insertion reactions of this kind of carbenoid species. The $\mathrm{C}-\mathrm{I}$ bond in $\mathrm{CH}_{2} \mathrm{I}-\mathrm{I}$ is fairly strong and is difficult to break and give an $\mathrm{I}_{2}$ leaving group which would lead to a very high barrier to reaction and this is not likely to occur. The cyclopropanation reaction of $\mathrm{CH}_{2} \mathrm{I}-\mathrm{I}$ with ethylene occurs easily with a barrier of only $2.9 \mathrm{kcal} / \mathrm{mol}$ at the B3LYP/ Sadlej-pVTZ level of theory to produce a cyclopropane product and $\mathrm{I}_{2}$ leaving group because the $\mathrm{C}-\mathrm{I}$ bond cleavage is compensated by formation of two $\mathrm{C}-\mathrm{C}$ bonds of the cyclopropanation reaction. However, the $\mathrm{O}-\mathrm{H}$ insertion reaction of $\mathrm{CH}_{2} \mathrm{I}-\mathrm{I}$ with $\mathrm{H}_{2} \mathrm{O}$ does not have as much compensation in its bond formation processes and thus has barriers to reaction $>30 \mathrm{kcal} / \mathrm{mol}$ according to a preliminary search for its transition state and these types of reactions will not be considered further here.

Inspection of Fig. 4 reveals that formation of a reactant complex (IM4) between $\mathrm{CH}_{2} \mathrm{I}-\mathrm{I}$ and $\mathrm{H}_{2} \mathrm{O}$ leads to some $\mathrm{C}-\mathrm{H}^{\cdots} \mathrm{O}$ and $\mathrm{I} \cdots \mathrm{H}$ hydrogen bond formation $\left(\mathrm{H}-\mathrm{O}^{4}\right.$ distance of $2.441 \AA$ and $\mathrm{I}^{3}-\mathrm{H}^{5}$ distance of $3.022 \AA$ ). The hydrogen bondinglike interaction helps stabilize IM4 by about $4.2 \mathrm{kcal} / \mathrm{mol}$ relative to the separated reactants and the complex has a ringlike structure. The reactant complex (IM4) can then undergo the $\mathrm{O}-\mathrm{H}$ insertion reaction via TS5 to form $\mathrm{CH}_{2} \mathrm{IOH}+\mathrm{HI}$ products with a barrier to reaction of about $13.6 \mathrm{kcal} / \mathrm{mol}$ from IM4 to TS5. As the reactant complex (IM4) goes to TS5 the $\mathrm{C}-\mathrm{O}$ bond and the $\mathrm{H}-\mathrm{I}$ bonds become significantly stronger from $\mathrm{C}^{1}-\mathrm{O}^{4}$ and $\mathrm{I}^{3}-\mathrm{H}^{5}$ bond lengths of 3.161 and $3.022 \AA$, respectively, in IM4 to about 2.111 and $2.438 \AA$, respectively, in TS5. At the same time the I-I bond becomes significantly weaker (the $\mathrm{I}^{2}-\mathrm{I}^{3}$ bond length changes from $3.058 \AA$ in IM4 to $3.368 \AA$ in TS5) and the $\mathrm{C}-\mathrm{I}-\mathrm{I}$ angle decreases from $113.5^{\circ}$ in IM4 to $95.5^{\circ}$ in TS5. As the system goes from TS5 to the products, the $\mathrm{C}-\mathrm{O}$ bond strengthens from $2.111 \AA$ in TS5 to $1.383 \AA$ in the $\mathrm{CH}_{2} \mathrm{IOH}$ product while the $\mathrm{C}-\mathrm{I}$ bond weakens from $1.967 \AA$ in TS5 to $2.226 \AA$ in the $\mathrm{CH}_{2} \mathrm{IOH}$ product. IRC calculations confirmed that TS5 connected IM4 and to the $\mathrm{CH}_{2} \mathrm{IOH}$ and $\mathrm{HI}$ products. Vibrational analysis obtained one imaginary frequency at $396 \mathrm{i}$ for TS5 and this had a reaction vector of +0.80 $\mathrm{C}^{1}-\mathrm{O}^{4}-0.45 \mathrm{I}^{2}-\mathrm{I}^{3}-0.12 \mathrm{O}^{4}-\mathrm{H}^{5}$ that is consistent with the structural changes taking place as IM4 goes to TS5 and then to the $\mathrm{CH}_{2} \mathrm{IOH}$ and $\mathrm{HI}$ products.

The $\mathrm{CH}_{2} \mathrm{I}-\mathrm{I}+\mathrm{H}_{2} \mathrm{O}$ reaction shown in Fig. 4 is similar to that for the : $\mathrm{CCl}_{2}+\mathrm{H}_{2} \mathrm{O}$ reaction shown in Fig. 2 in that both reaction involve significant $\mathrm{C}-\mathrm{O}$ bond formation in their transition states that then leads to their $\mathrm{O}-\mathrm{H}$ insertion prod- ucts. These two $\mathrm{O}-\mathrm{H}$ insertion reactions also have similar barriers to reaction (about $14.7 \mathrm{kcal} / \mathrm{mol}$ for the $: \mathrm{CCl}_{2}$ $+\mathrm{H}_{2} \mathrm{O}$ reaction and $13.6 \mathrm{kcal} / \mathrm{mol}$ for the $\mathrm{CH}_{2} \mathrm{I}-\mathrm{I}+\mathrm{H}_{2} \mathrm{O}$ reaction from the MP2 calculations). Examination of the structural changes occurring in the two reactions in Figs. 2 and 4 shows that the $\mathrm{O}-\mathrm{H}$ bond cleavage process is taking place in their transition states. This $\mathrm{O}-\mathrm{H}$ bond cleavage process in the $\mathrm{O}-\mathrm{H}$ insertion reactions is accompanied by $\mathrm{C}-\mathrm{O}$ and $\mathrm{C}-\mathrm{H}$ bond formation in TS1 for the $: \mathrm{CCl}_{2}+\mathrm{H}_{2} \mathrm{O}$ reaction and accompanied by $\mathrm{C}-\mathrm{O}$ and $\mathrm{H}-\mathrm{I}$ bond formation in TS1 for the $\mathrm{CH}_{2} \mathrm{I}-\mathrm{I}+\mathrm{H}_{2} \mathrm{O}$ reaction. This and the very weak I-I bond being broken to make the HI leaving group in the $\mathrm{CH}_{2} \mathrm{I}-\mathrm{I}+\mathrm{H}_{2} \mathrm{O}$ reaction helps explain why the barriers to the $\mathrm{O}-\mathrm{H}$ insertion reactions are similar for both the $: \mathrm{CCl}_{2}$ $+\mathrm{H}_{2} \mathrm{O}$ and the $\mathrm{CH}_{2} \mathrm{I}-\mathrm{I}+\mathrm{H}_{2} \mathrm{O}$ reactions.

The results presented in Figs. 4 and 5 show that the reaction of $\mathrm{CH}_{2} \mathrm{I}-\mathrm{I}$ with $2 \mathrm{H}_{2} \mathrm{O}$ is noticeably different from that of $\mathrm{CH}_{2} \mathrm{I}-\mathrm{I}$ with $\mathrm{H}_{2} \mathrm{O}$. The second $\mathrm{H}_{2} \mathrm{O}$ molecule appears to catalyze the $\mathrm{O}-\mathrm{H}$ insertion/HI elimination reaction by significantly altering the stability of the reaction complex and the transition state for the reaction. The second water molecule increases the stability of the reactant complex (IM5) by an additional $7.7 \mathrm{kcal} / \mathrm{mol}$ relative to IM4 and the transition state TS6 is stabilized by about $11 \mathrm{kcal} / \mathrm{mol}$ relative to TS5. The transition state is stabilized more than the reactant complex and this causes the barrier to reaction to decrease noticeably from $13.66 \mathrm{kcal} / \mathrm{mol}$ from IM4 to TS5 to about 10.3 $\mathrm{kcal} / \mathrm{mol}$ from IM5 to TS6. The barrier to reaction from the separated reactants to TS5 is substantial for the $\mathrm{CH}_{2} \mathrm{I}-\mathrm{I}$ $+\mathrm{H}_{2} \mathrm{O}$ reaction (see Fig. 4) with a value of $9.4 \mathrm{kcal} / \mathrm{mol}$. However, the transition state TS6 for the $\mathrm{CH}_{2} \mathrm{I}-\mathrm{I}+2 \mathrm{H}_{2} \mathrm{O}$ reaction is below the energy for the separated reactants and this reaction may occur relatively easily. IRC calculations confirmed that TS6 connected IM5 and to the $\mathrm{CH}_{2} \mathrm{IOH}, \mathrm{HI}$, and $\mathrm{H}_{2} \mathrm{O}$ products. Vibrational analysis obtained one imaginary frequency at $319 \mathrm{i}$ for TS6 and this had a reaction vector of $+0.59 \mathrm{C}^{1}-\mathrm{O}^{5}-0.52 \mathrm{I}^{2}-\mathrm{I}^{3}+0.23 \mathrm{I}^{3}-\mathrm{H}^{8}$ that is consistent with the structural changes taking place as IM5 goes to TS6 and then to the $\mathrm{CH}_{2} \mathrm{IOH}, \mathrm{HI}$, and $\mathrm{H}_{2} \mathrm{O}$ products.

It is instructive to compare the structures for the reactant complexes and transition states for the $\mathrm{CH}_{2} \mathrm{I}-\mathrm{I}+\mathrm{H}_{2} \mathrm{O}$ and $\mathrm{CH}_{2} \mathrm{I}-\mathrm{I}+2 \mathrm{H}_{2} \mathrm{O}$ reactions to better understand how the second $\mathrm{H}_{2} \mathrm{O}$ molecule alters the reaction pathway. Both IM4 and IM5 have a ringlike structure with the $\mathrm{H}_{2} \mathrm{O}$ molecule(s) interacting with the carbon atom and the terminal I atom of the $\mathrm{CH}_{2} \mathrm{I}-\mathrm{I}$ species. However, addition of the second water molecule significantly alters this interaction to cause greater $\mathrm{H}-\mathrm{I}$ bond formation in IM5 $\left(\mathrm{H}^{7}-\mathrm{I}^{3}\right.$ bond length of $\left.2.794 \AA\right)$ than in IM4 $\left(\mathrm{H}^{5}-\mathrm{I}^{3}\right.$ bond length of $\left.3.022 \AA\right)$. The second water molecule also leads to greater interaction between one of the carbon hydrogen atoms and the $\mathrm{O}$ atom of the water molecule forming the $\mathrm{C}-\mathrm{O}$ bond (distance of about $2.086 \AA$ in IM5 compared to $2.441 \AA$ in IM4). These greater $\mathrm{H}-\mathrm{I}$ bond formation and hydrogen interaction helps IM5 become more stable than IM4. As IM5 goes to TS6 the $\mathrm{C}-\mathrm{O}$ bond becomes significantly stronger (from $3.077 \AA$ in IM5 to $2.193 \AA$ in TS6) and this is similar to the changes occurring as IM4 goes to TS5 (from $3.1601 \AA$ in IM4 to $2.111 \AA$ in TS5). The changes in the $\mathrm{C}-\mathrm{I}$ and $\mathrm{I}-\mathrm{I}$ bonds are also similar between 


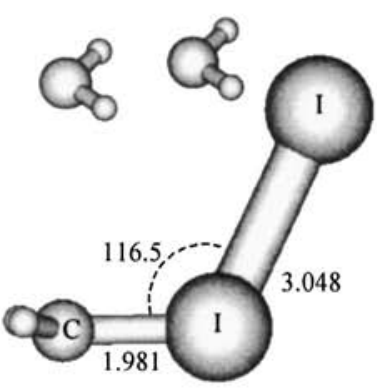

$\mathrm{CH}_{2} \mathrm{I}-\mathrm{I}+2 \mathrm{H}_{2} \mathrm{O}$

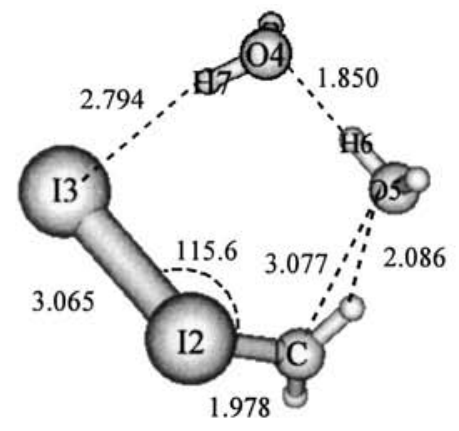

IM5
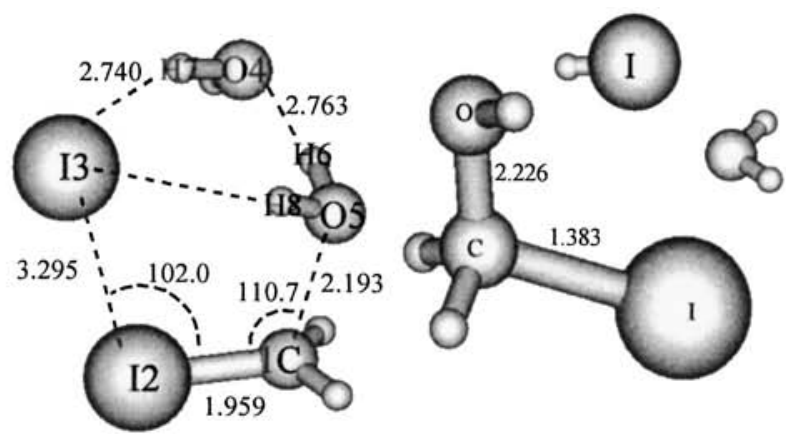

TS6

\section{$\mathrm{CH}_{2} \mathrm{IOH}+\mathrm{H}_{2} \mathrm{O}+\mathrm{HI}$}

(a)

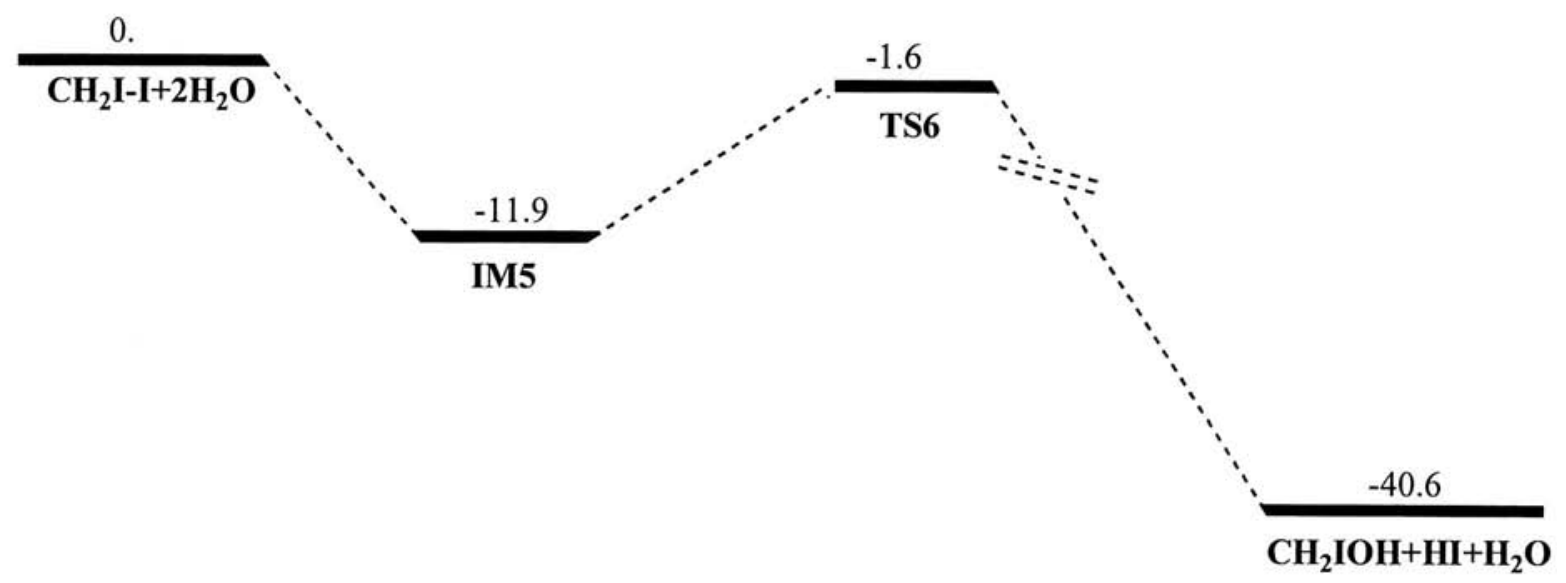

(b)

FIG. 5. (a) Schematic diagram of the MP2 computed optimized geometry for selected reactants, intermediates, transition states and products for the reactions of $\mathrm{CH}_{2} \mathrm{I}-\mathrm{I}+2 \mathrm{H}_{2} \mathrm{O}$. Selected geometry parameters are given with bond lengths in $\AA$ and bond angles in degrees. (b) Relative energy profiles (in kcal/mol) are displayed for the $\mathrm{CH}_{2} \mathrm{I}-\mathrm{I}+2 \mathrm{H}_{2} \mathrm{O}$ reaction from the MP2 calculations.

the two reactions as their reactant complexes go to their transition states (see Figs. 4 and 5). However, there is a significant difference between the two reactions in the changes occurring for the $\mathrm{H}-\mathrm{I}$ bond. There is little change as IM5 goes to TS6 for the initial $\mathrm{H}^{7}-\mathrm{I}$ hydrogen bond $\left(\mathrm{H}^{7}-\mathrm{I}\right.$ bond lengths of $2.794 \AA$ in IM5 to $2.740 \AA$ in TS6) compared to the change as IM4 goes to TS5 (H-I bond lengths of $3.022 \AA$ in IM4 to $2.438 \AA$ in TS5). This suggests that TS6 is somewhat closer in structure to IM5 than TS5 is to IM4 and probably needs less energy for IM5 to reach TS6 than for IM4 to reach TS5. This is consistent with the $\mathrm{CH}_{2} \mathrm{I}-\mathrm{I}+2 \mathrm{H}_{2} \mathrm{O}$ reaction having a lower barrier to reaction $(10.3 \mathrm{kcal} / \mathrm{mol}$ from IM5 to TS6) than the $\mathrm{CH}_{2} \mathrm{I}-\mathrm{I}+\mathrm{H}_{2} \mathrm{O}$ reaction $(13.6 \mathrm{kcal} / \mathrm{mol}$ from IM4 to TS5). As IM5 goes to TS6, the $\mathrm{H}^{6}-\mathrm{O}^{5}-\mathrm{H}^{8}$ water molecule rotates somewhat to provide a second hydrogen bonding interaction with the terminal I atom via a shorter $\mathrm{H}^{8}-\mathrm{I}^{3}$ distance of $2.827 \AA$. This helps stabilize TS6 compared to IM5 and suggests the hydrogen-bonding interaction between the two $\mathrm{H}_{2} \mathrm{O}$ molecules helps keep the $\mathrm{H}-\mathrm{I}$ leaving group distance of $\mathrm{I}^{3}-\mathrm{H}^{7}$ become more similar to that in IM5 while allowing the $\mathrm{C}-\mathrm{O}$ bond formation to take place as IM5 goes to TS6. As the $\mathrm{H}^{6}-\mathrm{O}^{5}-\mathrm{H}^{8}$ water molecule rotates, the $\mathrm{CH}_{2}$ group also rotates so that the $\mathrm{I}^{2}-\mathrm{C}^{1}-\mathrm{O}^{4}$ atoms form a plane that bisects the $\mathrm{CH}_{2}$ group. The changes in the TS6 structure show that it appears to become more cagelike than the IM5 structure. This may be due to more hydrogen bond interactions with the H-I leaving group and a more solvated environment around the leaving group. Thus, the second water molecule facilitates smaller changes taking place in the $\mathrm{HI}$ leaving group while the $\mathrm{C}-\mathrm{O}$ bond formation occurs as the reaction proceeds from IM5 to TS6. This leads to less energy being needed to get from IM5 to TS6 in the $\mathrm{CH}_{2} \mathrm{I}-\mathrm{I}+2 \mathrm{H}_{2} \mathrm{O}$ reaction compared to IM4 going to TS5 in the $\mathrm{CH}_{2} \mathrm{I}-\mathrm{I}+\mathrm{H}_{2} \mathrm{O}$ reaction. 
The $\mathrm{CH}_{2} \mathrm{I}-\mathrm{I}+2 \mathrm{H}_{2} \mathrm{O} \mathrm{O}-\mathrm{H}$ insertion/HI elimination reaction displays some similarities to the : $\mathrm{CCl}_{2}+2 \mathrm{H}_{2} \mathrm{O} \mathrm{O}-\mathrm{H}$ insertion reaction (compare Figs. 3 and 5). In both reactions, the second water molecule helps to significantly stabilize both the reactant complexes and the transition states relative to their corresponding reactions with one water molecule. This facilitates the catalysis of each reaction by enabling less structural changes in the second bond formation of $\mathrm{C}-\mathrm{H}$ bond in the dichlorocarbene reactions or the $\mathrm{HI}$ leaving group formation in the $\mathrm{CH}_{2} \mathrm{I}-\mathrm{I}$ reactions between the reactant complex and its transition state. For example, the : $\mathrm{CCl}_{2}+\mathrm{H}_{2} \mathrm{O}$ reaction has a $\mathrm{C}-\mathrm{H}$ bond distances of $2.882 \AA$ in IM1 compared to $1.239 \AA$ in TS1 compared to $2.117 \AA$ in IM3 and $1.650 \AA$ in TS3 for the $: \mathrm{CCl}_{2}+2 \mathrm{H}_{2} \mathrm{O}$ reaction. Similarly, the $\mathrm{CH}_{2} \mathrm{I}-\mathrm{I}+\mathrm{H}_{2} \mathrm{O}$ reaction has a $\mathrm{H}-\mathrm{I}$ bond distances of $3.022 \AA$ in IM4 compared to $2.438 \AA$ in TS5 compared to $2.794 \AA$ in IM5 and $2.740 \AA$ in TS6 for the $\mathrm{CH}_{2} \mathrm{I}-\mathrm{I}+2 \mathrm{H}_{2} \mathrm{O}$ reaction. The second water molecule in the $\mathrm{CH}_{2} \mathrm{I}-\mathrm{I}+2 \mathrm{H}_{2} \mathrm{O}$ reaction appears to catalyze this reaction in a manner similar to that previously reported for the : $\mathrm{CCl}_{2}$ $+2 \mathrm{H}_{2} \mathrm{O}$ reaction. ${ }^{78,79}$

\section{Potential implications for atmospheric chemistry}

Our present results suggest that isopolyhalomethanes like $\mathrm{CH}_{2} \mathrm{I}-\mathrm{I}$ can undergo $\mathrm{O}-\mathrm{H}$ insertion/HX elimination reactions with water and water can also catalyze these reactions so they may be able to take place fairly easily. These $\mathrm{O}-\mathrm{H}$ insertion/HX elimination reactions would release hydrogen halide products (like $\mathrm{HI}$ respectively in the case of $\mathrm{CH}_{2} \mathrm{I}-\mathrm{I}$ examined here). Thus, the water-catalyzed $\mathrm{O}-\mathrm{H}$ insertion/HX elimination reactions of isopolyhalomethanes may be a noticeable source of halogens and/or acid formation in the atmosphere. To our knowledge these types of reactions have not yet been considered for the photochemistry of polyhalomethanes (such as $\mathrm{CH}_{2} \mathrm{I}_{2}, \mathrm{CH}_{2} \mathrm{BrI}, \mathrm{CH}_{2} \mathrm{Br}_{2}$, $\mathrm{CHBr}_{3}, \mathrm{CCl}_{4}, \mathrm{CCl}_{3} \mathrm{~F}$, and others) that are known to be present from natural and/or manmade sources. The water catalyzed $\mathrm{O}-\mathrm{H}$ insertion/HX elimination reactions of isopolyhalomethanes are expected to be phase dependent photochemistry for several reasons. First, the isopolyhalomethanes appear to be mainly formed via geminate recombination of the initially produced photoproducts within their immediate solvent cage. ${ }^{51-55,57,63}$ This implies a solvated environment (such as the interfacial or bulk regions of water or ice particles) for the polyhalomethane molecule is needed to form appreciable amounts of isopolyhalomethane molecules. Second, the isopolyhalomethanes are generally unstable species and do not have very long lifetimes at most temperatures relevant to the natural environment and thus would not travel very far before they undergo isomerization back to their parent molecule. This would make gas-phase reactions with isopolyhlaomethanes very unlikely to occur. Third, the presence of two or more water molecules in the immediate vicinity of the relatively short-lived isopolyahalomethane species is needed for appreciable water catalyzed $\mathrm{O}-\mathrm{H}$ insertion/HI elimination reactions to occur.

While water catalyzed $\mathrm{O}-\mathrm{H}$ insertion/HX elimination reactions of isopolyhalomethanes are unlikely to take place in the gas phase because of the preceding three reasons, they may take place to a noticeable degree in a solvated aqueous medium (such as the interfacial and/or bulk regions of water and ice particles). Our recent picosecond time-resolved resonance Raman study observed the formation and decay of $\mathrm{CH}_{2} \mathrm{I}-\mathrm{I}$ in largely aqueous solvents and indicates that isopolyhalomethanes like $\mathrm{CH}_{2} \mathrm{I}-\mathrm{I}$ can be formed to a noticeable degree via geminate recombination of the $\mathrm{CH}_{2} \mathrm{I}$ radical and I fragments in aqueous environments following ultraviolet photolysis of $\mathrm{CH}_{2} \mathrm{I}_{2} \cdot{ }^{80}$ Since a range of isopolyhalomethanes have been observed in room temperature solutions in both nonpolar and polar solvents (like cyclohexane and acetonitrile, respectively), ${ }^{53-63}$ it is likely that a number of isopolyhalomethanes can be produced in noticeable quantities in aqueous solvents as observed for other solvent systems. This would suggest it would be prudent to investigate the possible reactions of these isopolyhalomethanes in aqueous environments. We note that our present results suggest the release of $\mathrm{HX}$ and its associated $\mathrm{pH}$ change of an aqueous solution would be an indicator for the likely presence of water catalyzed $\mathrm{O}-\mathrm{H}$ insertion reactions of isopolyhalomethane species with water following ultraviolet photolysis of polyhalomethanes. Further theoretical and experimental work is ongoing to better understand the chemical reactivity of isopolyhalomethanes in aqueous environments and whether they may make a noticeable contribution to the photochemistry of polyhalomethanes found in aqueous media and potentially to atmospheric chemistry.

\section{CONCLUSION}

We presented ultraviolet/visible absorption and $\mathrm{pH}$ measurements that indicate significant production of $\mathrm{H}^{+}$and $\mathrm{I}^{-}$ products following ultraviolet photolysis of $\mathrm{CH}_{2} \mathrm{I}_{2}$ in liquid water. The chemical reactivity of isodiiodomethane $\left(\mathrm{CH}_{2} \mathrm{I}-\mathrm{I}\right)$ with $\mathrm{H}_{2} \mathrm{O}$ and $2 \mathrm{H}_{2} \mathrm{O}$ was explored using ab initio calculations and compared to previous results in the literature for the related dichlorocarbene $\left(: \mathrm{CCl}_{2}\right)$ reactions with $\mathrm{H}_{2} \mathrm{O}$ and $2 \mathrm{H}_{2} \mathrm{O}$. The $\mathrm{CH}_{2} \mathrm{I}-\mathrm{I}$ isopolyhalomethane species was found to react with water by an $\mathrm{O}-\mathrm{H}$ insertion/HI elimination reaction mechanism that forms a $\mathrm{HI}$ leaving group. In contrast, the $\mathrm{O}-\mathrm{H}$ insertion reaction of the $: \mathrm{CCl}_{2}$ species required no leaving group and the differences in the : $\mathrm{CCl}_{2}$ and $\mathrm{CH}_{2} \mathrm{I}-\mathrm{I} \mathrm{O}-\mathrm{H}$ insertion reactions can be explained by their differing structures and properties. The $\mathrm{CH}_{2} \mathrm{I}-\mathrm{I}$ species $\mathrm{O}-\mathrm{H}$ insertion/HI elimination reactions can be catalyzed by a second water molecule when two water molecules are present and this catalysis process occurs in a manner similar to that found previously for the reaction of : $\mathrm{CCl}_{2}$ with two water molecules. Our results suggest that $\mathrm{CH}_{2} \mathrm{I}-\mathrm{I}$ and other isopolyhalomethane molecules may be fairly reactive towards $\mathrm{O}-\mathrm{H}$ bonds in water similar to other carbenoid species. Our results also suggest that the HX acid leaving group may be indicative of the presence of these water catalyzed $\mathrm{O}-\mathrm{H}$ insertion reaction of the isopolyhalomethane photoproduct generated from the ultraviolet photolysis of polyhalomethanes in aqueous environments. Some potential implications for the photochemistry of polyhalomethanes in the atmosphere and oceans were briefly discussed. 


\section{ACKNOWLEDGMENTS}

This work was supported by grants from the Research Grants Council (RGC) of Hong Kong (HKU 7087/01P), the Committee on Research and Conference Grants (CRCG) from the University of Hong Kong, and the Large Items of Equipment Allocation 1993-94 from the University of Hong Kong.

${ }^{1}$ Th. Class and K. Ballschmiter, J. Atmos. Chem. 6, 35 (1988).

${ }^{2}$ S. Klick and K. Abrahamsson, J. Geophys. Res. [Oceans] 97, 12683 (1992).

${ }^{3}$ K. G. Heumann, Anal. Chim. Acta 283, 230 (1993).

${ }^{4}$ R. M. Moore, M. Webb, R. Tokarczyk, and R. Wever, J. Geophys. Res., [Oceans] 101, 20899 (1996).

${ }^{5}$ J. C. Mössigner, D. E. Shallcross, and R. A. Cox, J. Chem. Soc., Faraday Trans. 94, 1391 (1998).

${ }^{6}$ C. T. McElroy, C. A. McLinden, and J. C. McConnell, Nature (London) 397, 338 (1999).

${ }^{7}$ L. J. Carpenter, W. T. Sturges, S. A. Penkett, and P. S. Liss, J. Geophys. Res. [Oceans] 104, 1679 (1999).

${ }^{8}$ B. Alicke, K. Hebstreit, J. Stutz, and U. Platt, Nature (London) 397, 572 (1999)

${ }^{9}$ H. E. Simmons and R. D. Smith, J. Am. Chem. Soc. 81, 4256 (1959).

${ }^{10}$ D. C. Blomstrom, K. Herbig, and H. E. Simmons, J. Org. Chem. 30, 959 (1965).

${ }^{11}$ N. J. Pienta and P. J. Kropp, J. Am. Chem. Soc. 100, 655 (1978).

${ }^{12}$ P. J. Kropp, N. J. Pienta, J. A. Sawyer, and R. P. Polniaszek, Tetrahedron 37, 3229 (1981)

${ }^{13}$ P. J. Kropp, Acc. Chem. Res. 17, 131 (1984).

${ }^{14}$ E. C. Friedrich, S. E. Lunetta, and E. J. Lewis, J. Org. Chem. 54, 2388 (1989).

${ }^{15}$ S. Durandetti, S. Sibille, and J. Pérchon, J. Org. Chem. 56, 3255 (1991).

${ }^{16}$ J. M. Concellón, P. L. Bernad, and J. A. Pérez-Andrés, Tetrahedron Lett. 39, 1409 (1998)

${ }^{17}$ M. Kawasaki, S. J. Lee, and R. Bersohn, J. Chem. Phys. 63, 809 (1975).

${ }^{18}$ G. Schmitt, F. J. Comes, J. Photochem. 14, 107 (1980)

${ }^{19}$ P. M. Kroger, P. C. Demou, S. J. Riley, J. Chem. Phys. 65, 1823 (1976).

${ }^{20}$ J. B. Koffend and S. R. Leone, Chem. Phys. Lett. 81, 136 (1981).

${ }^{21}$ S. R. Cain, R. Hoffman, and R. Grant, J. Phys. Chem. 85, 4046 (1981).

${ }^{22}$ S. J. Lee and R. Bersohn, J. Phys. Chem. 86, 728 (1982).

${ }^{23}$ L. J. Butler, E. J. Hintsa, and Y. T. Lee, J. Chem. Phys. 84, 4104 (1986).

${ }^{24}$ L. J. Butler, E. J. Hintsa, and Y. T. Lee, J. Chem. Phys. 86, 2051 (1987).

${ }^{25}$ E. A. J. Wannenmacher, P. Felder, and J. R. Huber, J. Chem. Phys. 95, 986 (1991).

${ }^{26}$ G. Baum, P. Felder, and J. R. Huber, J. Chem. Phys. 98, 1999 (1993).

${ }^{27}$ U. Marvet and M. Dantus, Chem. Phys. Lett. 256, 57 (1996).

${ }^{28}$ Q. Zhang, U. Marvet, and M. Dantus, J. Chem. Phys. 109, 4428 (1998).

${ }^{29}$ K.-W. Jung, T. S. Ahmadi, and M. A. El-Sayed, Bull. Korean Chem. Soc. 18, 1274 (1997).

${ }^{30}$ W. Radloff, P. Farmanara, V. Stert, E. Schreiber, and J. R. Huber, Chem. Phys. Lett. 291, 173 (1998).

${ }^{31}$ K. Kavita and P. K. Das, J. Chem. Phys. 112, 8426 (2000).

${ }^{32}$ S. L. Baughcum, H. Hafmann, S. R. Leone, and D. Nesbitt, Faraday Discuss. Chem. Soc. 67, 306 (1979).

${ }^{33}$ S. L. Baughcum and S. R. Leone, J. Chem. Phys. 72, 6531 (1980).

${ }^{34}$ J. Zhang and D. G. Imre, J. Chem. Phys. 89, 309 (1988).

${ }^{35}$ W. M. Kwok and D. L. Phillips, Chem. Phys. Lett. 235, 260 (1995); 241, 267 (1995)

${ }^{36}$ S. Q. Man, W. M. Kwok, and D. L. Phillips, J. Phys. Chem. 99, 15705 (1995).

${ }^{37}$ W. M. Kwok and D. L. Phillips, J. Chem. Phys. 104, 2529 (1996).

${ }^{38}$ W. M. Kwok and D. L. Phillips, J. Chem. Phys. 104, 9816 (1996).

${ }^{39}$ S. Q. Man, W. M. Kwok, A. E. Johnson, and D. L. Phillips, J. Chem. Phys. 105, 5842 (1996).

${ }^{40}$ F. Duschek, M. Schmitt, P. Vogt, A. Materny, and W. Kiefer, J. Raman Spectrosc. 28, 445 (1997).

${ }^{41}$ M. Braun, A. Materny, M. Schmitt, W. Kiefer, and V. Engel, Chem. Phys. Lett. 284, 39 (1998)

${ }^{42}$ X. Zheng and D. L. Phillips, Chem. Phys. Lett. 313, 467 (1999).

${ }^{43}$ D. L. Phillips, Prog. React. Kinet. Mech. 24, 223 (1999).

${ }^{44}$ J. P. Simons and P. E. R. Tatham, J. Chem. Soc. A 77, 854 (1966).
${ }^{45}$ H. Mohan, K. N. Rao, and R. M. Iyer, Radiat. Phys. Chem. 23, 505 (1984).

${ }^{46}$ G. Maier and H. P. Reisenauer, Angew. Chem., Int. Ed. Engl. 25, 819 (1986).

${ }^{47}$ G. Maier, H. P. Reisenauer, J. Lu, L. J. Scaad, and B. A. Hess, Jr., J. Am. Chem. Soc. 112, 5117 (1990).

${ }^{48}$ L. Andrews, F. T. Prochaska, and B. S. Ault, J. Am. Chem. Soc. 101, 9 (1979).

${ }^{49}$ H. Mohan and R. M. Iyer, Radiat. Eff. 39, 97 (1978).

${ }^{50}$ H. Mohan and P. N. Moorthy, J. Chem. Soc., Perkin Trans. 2 2, 277 (1990).

${ }^{51}$ B. J. Schwartz, J. C. King, J. Z. Zhang, and C. B. Harris, Chem. Phys. Lett. 203, 503 (1993).

${ }^{52}$ K. Saitow, Y. Naitoh, K. Tominaga, and Y. Yoshihara, Chem. Phys. Lett. 262, 621 (1996)

${ }^{53}$ A. N. Tarnovsky, J.-L. Alvarez, A. P. Yartsev, V. Sündstrom, and E. Åkesson, Chem. Phys. Lett. 312, 121 (1999).

${ }^{54}$ A. N. Tarnovsky, M. Wall, M. Rasmusson, T. Pascher, and E. Åkesson, J. Chin. Chem. Soc. (Taipei) 47, 769 (2000).

${ }^{55}$ A. N. Tarnovsky, M. Wall, M. Gustafsson, N. Lascoux, V. Sundström, and E. Åkesson, J. Phys. Chem. A 106, 5999 (2002).

${ }^{56}$ X. Zheng and D. L. Phillips, J. Phys. Chem. A 104, 6880 (2000).

${ }^{57}$ W. M. Kwok, C. Ma, A. W. Parker, D. Phillips, M. Towrie, P. Matousek, and D. L. Phillips, J. Chem. Phys. 113, 7471 (2000).

${ }^{58}$ X. Zheng and D. L. Phillips, Chem. Phys. Lett. 324, 175 (2000).

${ }^{59}$ X. Zheng and D. L. Phillips, J. Chem. Phys. 113, 3194 (2000).

${ }^{60}$ X. Zheng, W. M. Kwok, and D. L. Phillips, J. Phys. Chem. A 104, 10464 (2000).

${ }^{61}$ X. Zheng, W.-H. Fang, and D. L. Phillips, J. Chem. Phys. 113, 10934 (2000).

${ }^{62}$ X. Zheng, C. W. Lee, Y.-L. Li, W.-H. Fang, and D. L. Phillips, J. Chem. Phys. 114, 8347 (2001).

${ }^{63}$ W. M. Kwok, C. Ma, A. W. Parker, D. Phillips, M. Towrie, P. Matousek, X. Zheng, and D. L. Phillips, J. Chem. Phys. 114, 7536 (2001).

${ }^{64}$ D. L. Phillips, W.-H. Fang, and X. Zheng, J. Am. Chem. Soc. 123, 4197 (2001).

${ }^{65}$ D. L. Phillips and W.-H. Fang, J. Org. Chem. 66, 5890 (2001).

${ }^{66}$ Y.-L. Li, K. H. Leung, and D. L. Phillips, J. Phys. Chem. A 105, 10621 (2001).

${ }^{67}$ W.-H. Fang, D. L. Phillips, D. Wang, and Y.-L. Li, J. Org. Chem. 67, 154 (2002).

${ }^{68}$ Y.-L. Li, D. M. Chen, D. Wang, and D. L. Phillips, J. Org. Chem. 67, 4228 (2002).

${ }^{69}$ Y.-L. Li, D. Wang, and D. L. Phillips, J. Chem. Phys. 117, 7931 (2002).

${ }^{70}$ B. Zurawski and W. Kutzelnigg, J. Am. Chem. Soc. 100, 2654 (1978).

${ }^{71}$ S. Sakai, Int. J. Quantum Chem. 70, 291 (1998).

${ }^{72}$ L. B. Harding, H. B. Schlegel, R. Krishnan, and J. A. Pople, J. Phys. Chem. 84, 3394 (1980)

${ }^{73}$ C. Wesdemiotis, R. Feng, P. O. Danis, E. R. Williams, and F. W. Lafferty, J. Am. Chem. Soc. 108, 5847 (1986).

${ }^{74}$ B. F. Yates, W. J. Bouma, and L. Radom, J. Am. Chem. Soc. 109, 2250 (1987).

${ }^{75}$ S. P. Walch, J. Chem. Phys. 98, 3163 (1993).

${ }^{76}$ C. Gonzalez, A. Restrepo-Cossio, M. Márquez, and K. B. Wiberg, J. Am. Chem. Soc. 118, 5408 (1996)

${ }^{77}$ C. J. Moody and G. H. Whitman in Reactive Intermediates, edited by S. G. Davies (Oxford University Press, New York, 1992).

${ }^{78}$ J. R. Pliego, Jr., and W. B. De Almeida, J. Phys. Chem. 100, 12410 (1996).

${ }^{79}$ J. R. Pliego, Jr. and W. B. De Almeida, J. Phys. Chem. A 103, 3904 (1999).

${ }^{80}$ W. M. Kwok, C. Ma, A. W. Parker, D. Phillips, M. Towrie, P. Matousek, and D. L. Phillips, J. Phys. Chem. A 107, 2624 (2003).

${ }^{81}$ M. J. Frisch, G. W. Trucks, H. B. Schlegel et al., GAUSSIAN 98, Revision A.7, Gaussian, Inc., Pittsburgh PA, 1998.

${ }^{82}$ A. D. Becke, J. Chem. Phys. 98, 1372 (1993).

${ }^{83}$ A. P. Scott and L. Radom, J. Phys. Chem. 100, 16502 (1996).

${ }^{84}$ S. H. Vosko, L. Wilk, and M. Nusair, Can. J. Chem. 58, 1200 (1980).

${ }^{85}$ A. D. Becke, Phys. Rev. A 38, 3098 (1988).

${ }^{86}$ C. Lee, W. Yang, and R. G. Parr, Phys. Rev. B 37, 785 (1988).

${ }^{87}$ C. Gonzalez and H. B. Schlegel, J. Chem. Phys. 90, 2154 (1989).

${ }^{88}$ C. Gonzalez and H. B. Schlegel, J. Phys. Chem. 94, 5523 (1990). 
${ }^{89}$ See EPAPS Document No. E-JCPSA6-119-008333 for supporting information on the Cartesian coordinates, total energies and vibrational zeropoint energies for selected stationary structures given in Figs. 2-5. A direct link to this document may be found in the online article's
HTML reference section. The document may also be reached via the EPAPS homepage (http://www.aip.org/pubservs/epaps.html) or from ftp.aip.org in the directory /epaps/. See the EPAPS homepage for more information. 